\title{
Strategi UMKM dalam meningkatkan pendapatan dimasa pandemi Covid-19 guna mempertahankan kelangsungan usaha di era revolusi industri 4.0 (studi pada UMKM makanan dan minuman di Kabupaten Pasuruan)
}

\author{
Hermi Sularsih ${ }^{1 *}$; Akhamad Nasir ${ }^{2}$ \\ ${ }^{1}$ Prodi Akuntansi, Sekolah Tinggi Ilmu Ekonomi Gempol \\ ${ }^{2}$ Prodi Manajemen, Sekolah Tinggi Ilmu Ekonomi Gempol \\ *E-mail korespodensi : hermisularsihstieg@gmail.com
}

\begin{abstract}
The purpose of this research is to find a strategy to increase MSME income during the COVID-19 pandemic to maintain business continuity in the era of the Industrial Revolution 4.0. The general goal is to increase the knowledge of MSME actors during the COVID-19 pandemic and increase the income of small and medium enterprises (MSMEs) for business continuity in Pasuruan Regency in the era of the Industrial Revolution 4.0. The method used in this study is a qualitative method using descriptive techniques, such as data reduction, data presentation, and concluding SWOT analysis. Informants in this survey are the Office of Cooperatives and Micro Enterprises and SMEs in Pasuruan Regency. The results showed that the Matrix Internal Factors (IFAS) and External Factors (EFAS) showed that MSMEs in the food and beverage business were located in cell $V$ in identification, segment growth, investment choice, and specialization. The strategy that micro food and beverage businesses must be carried out in Pasuruan Regency to increase income to maintain their business in the face of the 4.0 industrial revolution. During the covid 19 pandemic, namely, on Strength Opportunity (SO), strategies used strength to take advantage of external opportunities were created.
\end{abstract}

Keywords: Strategy, Income, Industrial Revolution 4.0, MSME

\begin{abstract}
Abstrak
Tujuan dari penelitian ini adalah untuk menemukan strategi peningkatan pendapatan UMKM di masa pandemi COVID-19 guna mempertahankan kelangsungan usaha di era Revolusi Industri 4.0. Tujuan umum yang ingin dicapai adalah meningkatkan pengetahuan pelaku UMKM di masa pandemi COVID-19 dan meningkatkan pendapatan usaha kecil dan menengah (UMKM) untuk kelangsungan usaha di Kabupaten Pasuruan di era Revolusi Industri 4.0. Metode yang digunakan dalam penelitian ini adalah metode kualitatif dengan menggunakan teknik deskriptif, seperti reduksi data, penyajian data dan penarikan kesimpulan melalui analisis SWOT. Informan dalam survei ini adalah Dinas koperasi dan Usaha Mikro serta pelaku usaha UMKM di Kabupaten Pasuruan. Hasil penelitian bahwa Matrix Internal Factors (IFAS) dan External Factors (EFAS) menunjukkan bahwa UMKM pada usaha makanan dan minuman terletak di sel $\mathrm{V}$ berada pada posisi identifikasi, pertumbuhan segmen, pilihan investasi dan spesialisasi. Strategi yang harus dilakukan usaha mikro makanan dan minuman di Kabupaten Pasuruan dalam meningkatkan pendapatan guna mempertahankan kelangsungan usahanya menghadapi revolusi industri 4.0. di masa pandemi covid 19 yaitu pada Strength Opportunity (SO) dengan cara menciptakan strategi yang menggunaan kekuatan untuk memanfaatkan peluang eksternal.
\end{abstract}

Kata kunci: Strategi, Pendapatan, Revolusi Industri 4.0, UMKM 


\section{PENDAHULUAN}

Usaha Mikro Kecil dan Menengah. Usaha Mikro Kecil Menengah merupakan pihak yang memiliki andil cukup besar dalam pergerakan perekonomian nasional. Pada masa pandemi COVID-19 Usaha mikro, kecil, dan menengah (UMKM) menjadi sektor yang terkena dampak cukup besar, (Ramadhan, 2020). Adapun peneliti yang melakukan penelitian tentang UMKM yang terdampak dimasa pandemi COVID-19 merupakan sektor usaha yang kena dampak cukup besar diantaranya (Amri, 2020; Andika et al., 2020; Bahtiar \& Saragih, 2020; Damayanti et al., 2019; Mesran.dkk, 2020; Hanoatubun, S, 2020; Sugiri, 2020; Susanti et al., 2020). Strategi berperan penting dalam Sektor Usaha Mikro Kecil dan Menengah (UMKM) karena didalam Sektor Usaha Kecil Dan Menengah (UMKM) dalam upaya peningkatan pendapatan sangat diperlukan untuk menghadapi beberapa persoalan di masa pandemi covid-19, Salah satunya, penurunan angka penjualan yang akan menyebabkan terjadinya penurunan peningkatan pendapatan guna mempertahankan usahanya. Karena dampak virus corona, satu persatu pasar ritel modern, skala besar, mikro, hingga kecil mulai mengalami penurunan penghasilan (Amri, 2020).

Di masa pandemi covid-19 ini diperlukan strategi bagi UMKM untuk dapat terus mempertahankan bisnisnya dalam upaya peningkatan pendapatan di tengah pandemi ini guna mempertahankan kelangsungan UMKM (Hardilawati, 2020). Pemberdayaan Usaha Mikro di tengah arus globalisasi harus mampu mengahadapi tantangan global yang di akibatkan tingginya persaingan dengan meningkatkan inovasi produk dan jasa, pengembangan sumber daya manusia dan teknologi, serta perluasan area pemasaran. Hal ini sangat perlu dilakukan untuk menambah nilai jual UMKM itu sendiri, supaya dapat bersaing dengan produk-produk asing yang kian membanjiri industri dan manufaktur di Indonesia, dan mengingat UMKM adalah sektor ekonomi yang mampu menyerap tenaga kerja terbesar di Indonesia (Hardilawati, 2020; Sedyastuti, 2018; Susanti et al., 2020) maka strategi pada UMKM harus diterapkan guna mempertahankan kelangsungan UMKM. Berdasarkan dari latar belakang diatas , maka rumusan masalah dalam penelitian ini adalah bagaimana strategi UMKM dalam meningkatan pendapatan dimasa pandemi COVID-19 guna mempertahankan kelangsungan usaha di era revolusi industri 4.0. Adapun tujuan khusus pada penelitian ini yaitu untuk meningkatkan pengatahuan bagi pelaku UMKM dimasa pandemi COVID-19 dalam upaya peningkatan pendapatan guna kelangsungan usaha mikro kecil dan menengah (UMKM) di Kabupaten Pasuruan di era revolusi industri 4.0 .

\section{LANDASAN TEORI}

\section{Revolusi industri 4.0}

Industri 4.0 (revolusi industri keempat) merangkum tren perkembangan industri masa depan untuk mencapai proses manufaktur yang lebih cerdas, termasuk mengandalkan Cyber-Physical Systems (CPS), pengembangan Cyber-Physical Production Systems (CPPS), serta implementasi dan pengoperasian pabrik pintar. (Zhou et al., 2016) Industri 4.0 mengacu pada kemajuan teknologi terkini dengan internet sebagai teknologi pendukung, sehingga diperlukan bimbingan dan dukungan untuk penyelarasan strategis dan operasi bisnis(Koch et al., 2014). Kesiapan Industri 4.0 yang terukur dalam 9 dimensi prodak, pelanggan, operasi, teknologi, strategi, kepemimpinan, tata kelolah, buadya, orang (Schumacher et al., 2016).

\section{UMKM dalam menghadapi pandemi Covid-19}

Usaha kecil dan menengah (UKM) merupakan perusahaan yang berperan besar dalam menjaga situasi perekonomian Indonesia. Bisnis tersebut dapat bertahan dari krisis ekonomi yang menewaskan sebuah perusahaan besar Indonesia. Sejauh ini, upaya tersebut tetap dipertahankan keberadaannya dalam partisipasi negara dalam pengelolaan 
ekonomi. Masalah selanjutnya adalah ketika Organisasi Kesehatan Dunia (WHO) menjelaskan bahwa coronavirus (Cov) adalah virus yang menginfeksi sistem pernapasan. Infeksi virus ini disebut COVID 19. Wabah virus corona juga berdampak pada sektor investasi, perdagangan, usaha mikro dan kecil (UMKM). Selain itu, wisatawan yang datang ke tempat tujuan biasanya membeli oleh-oleh. Seiring menurunnya jumlah kunjungan wisatawan, begitu pula penjualan UMKM. (Thaha, 2020).

\section{Pengertian strategi}

Definisi strategi adalah sebagai penentu merek, produk, atau perusahaan pasar berdasarkan kerangka konseptual konsumen atau pembuat kebijakan. terutama ditentukan oleh faktor eksternal (Harian Netral, 2014).

\section{Pendapatan}

Pendapatan adalah keseluruhan penghasilan yang diterima baik dari sektor formal maupunnonformal yang dihitung dalam jangka waktu tertentu. (Senekal, 2021) mengukur pendapatan masyarakat bukanlah pekerjaan yang mudah, oleh karena itu BPS melakukan perhitungan pendapatan dengan menggunakan pengeluaran/ konsumsi masyarakat, Indikator Pendapatan (Satiti, 2014) antara lain: Pendapatan yang diterima perbulan, Pekerjaan, Anggaran biaya, Beban.

\section{Strategi penjualan}

Menjual merupakan ilmu serta seni individu yang dicoba oleh penjual guna mengajak orang lain supaya bersedia membeli benda ataupun jasa yang ditawarkan ( Ayu, 2020) ada 5 tipe strategi penjualan, antara lain sebagai berikut:( 1) Trade Selling ialah penjualan produk( benda ataupun jasa) lewat penyalur ataupun distributor. Produsen tidak menjual sendiri produknya ke konsumen akhir.( 2) Missionary Selling yaitu penjual ataupun produsen berupaya pengaruhi serta membujuk pembeli supaya membeli produk dari penyalur yang ditunjuk oleh industri.( 3) Technical Selling merupakan metode yang berupaya tingkatkan penjualan produk dengan membagikan nasihat serta anjuran kepada konsumen.(4) New Bussiness Selling ialah penjual berupaya mengganti suspect( calon pembeli potensial) jadi pembeli yang actual ataupun sebetulnya.( 5) Responsive Selling merupakan tugas penjual membagikan respon dari stimulus yang ditunjukkan oleh pembeli ataupun calon pembeli.

\section{METODE}

\section{Populasi dan sampel}

Riset ini dilakukan pada Usaha Mikro Kecil dan Menengah( UMKM) Makanan serta Minuman yang terletak di 24 Kecamatan, Kabupaten Pasuruan. Ada pula informasi yang digunakan dalam riset ini merupakan informasi deskriptif kualitatif. Sebaliknya sumber informasi yang digunakan dalam riset ini merupakan informasi primer serta informasi sekunder. Populasi dalam riset ini ialah 2. 185 Usaha Makanan serta Minuman yang terdaftar di Dinas Koperasi dan Usaha Mikro di Kabupaten Pasuruan. Sampel merupakan sebagian ataupun wakil dari populasi yang hendak diteliti( Suharsimi, 2006) Pengambilan sampel bila subjeknya kurang dari 100 orang hendaknya diambil seluruhnya, bila subjeknya besar ataupun lebih dari 100 orang bisa diambil 10-15\% ataupun 20- 25\% ataupun lebih. Dari populasi tersebut diambil $20 \%$ dari populasi sehingga jumlah populasi $20 \%$ x $2.185=437$ responden. Alasan peneliti menggunakan $20 \%$ pada penentuan ukuran jumlah sampel karena: 1) Jumlah 2. 185 UKM bidang usaha 
Makanan tidak mungkin diambil semua menjadi sampel, 2) Supaya semua UKM terwakili selaku sampel.

\section{HASIL DAN PEMBAHASAN}

Dinas Koperasi dan Usaha Mikro Kabupaten Pasuruan menjelaskan, pada tahun 2021 sudah mencapai 211. 856 unit usaha. Trendnya bertambah dari tahun ke tahun. Dibanding dengan informasi jumlah pada tahun 2013, secara totalitas, jumlah UMKM bertambah sebanyak 6. 990 unit usaha ataupun sebesar 2, 79 persen. Kenaikan tersebut dibagi pada jumlah usaha mikro meningkat sebanyak 6. 489 unit, usaha kecil meningkat sebanyak 419 unit, serta udaha menengah meningkat sebanyak 82 unit. UMKM tersebut bergerak di 9 bagian usaha serta tersebar di 24 kecamatan di Kabupaten Pasuruan. Kenyataan tersebut layak menggembirakan, sebab menampilkan banyaknya penduduk yang berwirausaha di Kabupaten Pasuruan. Terus menjadi bertambahnya jumlah usaha mikro di Kabupaten Pasuruan diakibatkan sekian banyak aspek, misalkan akibat dari PHK( pemutusan ikatan kerja) yang berakibat pada opsi seorang buat membuka usaha, ataupun diakibatkan kemauan buat mempunyai bisnis di bidang tertentu. Tipe usaha mikro yang hadapi pertumbuhan sangat bermacam- macam, ialah mulai dari usaha santapan minuman( mamin). Perihal itu jadi kesempatan serta kemampuan kemandirian ekonomi daerah, sekalian jadi modal ketahanan perekonomian wilayah dari pengaruh eksternal yang sangat kilat berganti. Oleh karena itu, Pemerintah Kabupaten Pasuruan, sejalan dengan kebijakan pemerintah pusat, terus menerus berkomitmen, memfasilitasi serta mendesak tumbuhnya wirausaha baru serta melaksanakan bermacam upaya buat memantapkan wirausahawan yang sudah terdapat.

Analisis lingkungan internal terdiri dari variabel kekuatan dan kelemahan dan dilingkungan eksternal terdiri dari peluang dan ancaman yang ada diluar UMKM makanan dan minuman di Kabupaten Pasuruan. Hasil wawancara dan pengisian pertanyaan untuk mengevaluasi serta menempatkan factor internal dan factor eksternal dengan tepat sesuai permasalahan ada pada table 1 dan table 2 sebagai berikut:

Tabel 1. Internal factor analysis summary (IFAS) UMKM usaha makanan dan Minuman Kabupaten Pasuruan

\begin{tabular}{rlrrr}
\hline No & Strenghts (Kekuatan) & Bobot & Rating & \multicolumn{2}{c}{ Nilai } & \\
\hline 1 & Produk unik & 0,09 & 4 & 0,37 \\
2 & Haarga murah & 0,09 & 4 & 0,37 \\
3 & Mutu pelayanan & 0,06 & 3 & 0,19 \\
4 & Lokasi yang strategis & 0,09 & 4 & 0,37 \\
5 & SDM yang kreatif & 0,09 & 4 & 0,37 \\
6 & Bahan baku & 0,09 & 4 & 0,37 \\
\hline & Sub Total & $\mathbf{0 , 5 3}$ & & $\mathbf{2 , 0 6}$ \\
\hline Weaknesses (Kelemahan) & & & \\
1 & Produksi menggunkan teknologi lama & 0,03 & 2 & 0,06 \\
2 & Kurangnya pelatihan yang sesusi & 0,09 & 1 & 0,09 \\
3 & Permodalan terbatas & 0,09 & 1 & 0,09 \\
4 & Promosi belum luas & 0,09 & 2 & 0,18 \\
5 & Pemasaran dari mulut ke mulut & 0,09 & 2 & 0,18 \\
6 & Tidak memiliki sentra industri & 0,06 & 2 & 0,12 \\
\hline & Sub Total & $\mathbf{0 , 4 7}$ & & $\mathbf{0 , 7 5}$ \\
\hline & Total & $\mathbf{1 , 0 0}$ & & Rata-rata $\mathbf{2 , 8 1}$ \\
\hline
\end{tabular}

Sumber : Data diolah, 2021 
Matrik IFAS menghasilkan nilai dengan skor rata-rata 2,81 dari keseluruhan factor internal. Hal ini ditunjukkan hari nilai kekuatan (strength) sebesar 2,06 lebih besar dari skor kelemahan 0,75. Berdasarkan rata-rata dari keseluruhan posisi strategisnya dalam usaha makanan minuman memanfaatkan kekuatannya dan menyembunyikan kelemahannya jika perlu.

Tabel 2. Eksternal factor analysis summary (EFAS) UMKM usaha makanan dan minuman Kabupaten Pasuruan

\begin{tabular}{clrrr}
\hline No & Opportunities (Peluang) & Bobot & Rating & Nilai \\
\hline 1 & Permintaan Relatif Tinggi & 0,06 & 3 & 0,19 \\
2 & Adanya dukungan dari pemerintah & 0,09 & 4 & 0,38 \\
3 & Pembinaan kerjasama & 0,09 & 3 & 0,29 \\
4 & Terdapat Banyak Aplikasi Online & 0,09 & 4 & 0,38 \\
5 & Kemajuan teknologi & 0,09 & 4 & 0,38 \\
\hline & Sub Total & $\mathbf{0 , 4 5}$ & & $\mathbf{1 , 6 4}$ \\
\hline$\quad$ Threats (Ancaman) & 0,09 & 1 & 0,09 \\
\hline 1 & Harga bahan baku yang tidak stabil & 0,09 & 1 & 0,09 \\
2 & Persaingan harga & 0,06 & 3 & 0,19 \\
3 & Teknologi yang masih lemah & 0,09 & 1 & 0,09 \\
4 & Lokasi yang berdekatan & & & 0,09 \\
& Persaingan baru dengan produk yang & 0,09 & 1 & 0,9 \\
5 & sama & 0,54 & 1 & $\mathbf{0 , 6 8}$ \\
\hline & Kelangkaan bahan baku & $\mathbf{0 , 5 5}$ & & Rata-rata 2,32 \\
\hline & Sub Total & $\mathbf{1 , 0 0}$ & &
\end{tabular}

Sumber : Data diolah, 2021

Matrik EFAS menghasilkan nilai dengan total skor rata-rata 2,32. Hal ini juga ditunjukkan dengan hasil skor peluang sebesar 1,64 yang lebih besar dari ancaman 0,68. Berdasarkan rata-rata dari keseluruhan posisi strategisnya dalam usaha makanan dan minuman memanfaatkan peluang ekternal dan menghindari ancaman-ancaman yang ada.

\section{Matrik SWOT}

Matrik SWOT proses awal dalam perumusan strategi yang akan dilakukan dalam menikatkan pendapatan UMKM makanan dan minuman di Kabupaten Pasuruan. Analisis mengharuskan pelaku usaha untuk melaksanakan stategi yang tepat dengan melihat peluang-peluang dan kekuatan, disamping juga memperhatikan ancaman-ancaman dan kelemahan-kelemahan. Matrik ini menggambarkan secara jelas kondisi yang dihadapi usaha makanan dan minuman. Matrik ini digunakan untuk membantu menentukan empat jenis strategi yang tepat yaitu Stategi SO (kekuatan-peluang), Strategi WO (kelemahanpeluang), Startegi ST (kekuatan-ancaman), Strategi WT (kelemahan - ancaman) yang disesuaikan dengan kondisi UMKM makanan dan minuman di Kabupaten Pasuruan (Suhartini dan Setyowati, 2012).

Tabel 3. Matriks SWOT UMKM usaha makanan dan minuman di Kabupaten Pasuruan

\begin{tabular}{|c|c|c|}
\hline \multirow[t]{6}{*}{ Faktor Eksternal } & Opportunity (Peluang) & Threat(Ancama) \\
\hline & 1. Permintaan Relatif Tinggi & 1. Terbatasnya Modal \\
\hline & 2. Adanya Dukungan Dari & 2. Kondisi Ekonomi \\
\hline & Pemerintah & Tidak Stabil \\
\hline & 3. Pembinaan Kerjasama & 3. Masyarakat \\
\hline & 4. Terdapat Banyak Aplikasi & Mengenal Produk \\
\hline \multirow[t]{5}{*}{ Faktor Internal } & Online & 4. Pesaing Produk Dari \\
\hline & 5. Kemajuan Teknologi & Luar Kota \\
\hline & & 5. Naik Turunnya Harga \\
\hline & & Bahan Baku \\
\hline & & $\begin{array}{l}\text { 6. Kelangkaan } \\
\text { Baku }\end{array}$ \\
\hline
\end{tabular}




\begin{tabular}{|c|c|c|}
\hline Strength (Kekuatan) & Strategi SO & Strategi ST \\
\hline $\begin{array}{l}\text { 1. Produk Unik } \\
\text { 2. Harga Murah } \\
\text { 3. Mutu Pelayanan } \\
\text { 4. Lokasi yang strategis } \\
\text { 5. SDM Yang Kreatif } \\
\text { 6. Bahan Baku }\end{array}$ & $\begin{array}{l}\text { 1. Produk yang unik menjadi salah satu } \\
\text { kunci sukses dalam membangun } \\
\text { keberhasilah di dunia usaha,. Hal ini } \\
\text { disebabkan karena produk yang unik akan } \\
\text { menjadi salah satu hal yang akan menjadi } \\
\text { tarik masyarakat.. } \\
\text { 2. Harga yang relative murah menjadi } \\
\text { kekuatan untuk memenuhi kebutuhan } \\
\text { konsumen dari berbagai sektor } \\
\text { masyarakat mutu pelayanan juga sangat } \\
\text { 3.Peningkatan mutu secara } \\
\text { membantu dan harus dilakukan suan } \\
\text { maksimal. } \\
\text { 4. lokasi yang strategis akan dan mudah } \\
\text { dijangkau akan membantu peningkatan } \\
\text { keberhasilan usaha. } \\
\text { 5. Dengan adanya sumber daya manusia } \\
\text { (SDM) yang kreatif yang dapat } \\
\text { menciptakan ide-ide yang baru } \\
\text { 6. Pemilihan bahan baku yang mudah } \\
\text { diperoleh akan memberikan peluang } \\
\text { untuk kebutuhan masyarakat yang } \\
\text { konsumtif. }\end{array}$ & $\begin{array}{l}\text { 1. Memberikan pelatihan } \\
\text { desain produk untuk } \\
\text { menjadi daya tarik } \\
\text { masyarakat } \\
\text { 2. Menggunakan harga } \\
\text { yang relative murah } \\
\text { guna menghadapai } \\
\text { persaingan baru } \\
\text { dengan produk yang } \\
\text { sama mutu } \\
\text { 3. peningkatan dilakukan } \\
\text { pelayanan meningkatkan } \\
\text { untuk pelayanan } \\
\text { cintra baik pelan } \\
\text { pada konsumen. } \\
\text { 4. lokasi strategis akan } \\
\text { mampu menghadapi } \\
\text { persaingan } \\
\text { pangsa pasar. } \\
\text { 5. Metode yang baru } \\
\text { akan sangat membantu } \\
\text { proses pengembangan } \\
\text { dan keberhasilan } \\
\text { usaha. }\end{array}$ \\
\hline $\begin{array}{l}\text { Weekness (Kelemahan) } \\
\text { 1. Produksi Menggunakan } \\
\text { Teknologi Lama } \\
\text { 2. Kurangnya Pelatihan } \\
\text { Yang Sesuai } \\
\text { 3. Permodalan Terbatas } \\
\text { 4. Promosi Belum Luas } \\
\text { 5. Pemasaran Dari Mulut } \\
\text { Ke Mulut } \\
\text { 6. Tidak Memiliki Sentra } \\
\text { Industri }\end{array}$ & $\begin{array}{l}\text { Strategi WO } \\
\text { 1. sentral industri penggunaan teknologi } \\
\text { baru sangat dibutuhkan untuk } \\
\text { pengembangan keberhasilan UMKM } \\
\text { apalagi di era revolusi industri } 4.0 \\
\text { penggunaan teknologi baru sangat } \\
\text { dibutuhkan dalam perkembangan dan } \\
\text { keberhasilan usaha. } \\
\text { 2. Mengikutkan pelatihan SDM sesuai } \\
\text { keperluan. } \\
\text { 3. Dukungan Pemerintah dalam usaha } \\
\text { pemberian bantuan modal dengan } \\
\text { pinjaman kredit lunak serta mengandeng } \\
\text { pemerintah daerah untuk melakukan } \\
\text { kerjasama penggunaan produk lokal. } \\
\text { 4. mempermosikan secara luas melalui } \\
\text { tersedianya aplikasi yang bisa dipakai } \\
\text { sebagai sarana promosi di sosial media } \\
\text { agar UMKM Pasuruan dapat dikenal } \\
\text { secara luas } \\
\text { 5. Mengusulkan pada pemerintah untuk } \\
\text { membuat sentral industri di tempat yang } \\
\text { strategis. }\end{array}$ & $\begin{array}{l}\text { Strategi WT } \\
\text { 1. Memaksimalkan } \\
\text { kinerja SDM dalam } \\
\text { penggunaan teknologi } \\
\text { terbaru } \\
\text { 2. Melakukan pemasaran } \\
\text { dengan intensif dan } \\
\text { konsisten. } \\
\text { 3. Memasarkan produk } \\
\text { berbasis internet. }\end{array}$ \\
\hline
\end{tabular}

Sumber : Data diolah, 2021

Berdasarkan hasil matrik swot skor tertinggi yaitu strategi Strength Opportunity (SO) adalah 3,7, strategi Strength Threat (ST) adalah 2,74, strategi Weakness Opportunity (WO) adalah 2,39 dan strategi Weakness Threat (WT) adalah 1,43. Strategi yang harus dilakukan usaha mikro makanan dan minuman di Kabupaten Pasuruan dalam meningkatkan pendapatan guna mempertahankan usahanya dalam menghadapi revolusi industri 4.0. di masa pandemi covid 19 yaitu pada strategi SO dengan cara menciptakan strategi yang menggunaan kekuatan untuk memanfaatkan peluang eksternal. 
Tabel 4. Rumusan kombinasi strategi matrik SWOT

\begin{tabular}{lll}
\hline EFAS & Opportunities $(\mathbf{O})$ & Threats $(\mathbf{T})$ \\
IFAS & & \\
\hline Strengths (S) & Strategi (SO) : & Strategi (ST) : \\
& $=2,06+1,64$ & $=2,06+0,68$ \\
& $=3,7$ & $=2,74$ \\
Weaknesses (W) & Strategi (WO) : & Strategi (WT) : \\
& $=0,75+1,64$ & $=0,75+0,68$ \\
& $=2,39$ & $=1,43$ \\
\hline
\end{tabular}

Sumber : Data diolah, 2021

\section{Analisis internal eksternal (IE) Matrix}

Matriks IFAS menunjukkan bahwa untuk faktor kekuatan skornya adalah 2,06 dan untuk faktor kelemahan skornya adalah 0,75. Sedangkan Matriks EFAS faktor peluang. skor 1,64 dan faktor ancaman 0,68. Dari hasil perhitungan penjumlahan hasil pada tabel 2 menunjukkan, faktor internal memiliki skor total 2,81 dan pada tabel 3 menunjukkan, faktor eksternal dengan skor total 2,32. Dengan demikian, matriks IE digunakan untuk mengetahui bagaimana posisi UMKM pada Usaha Makanan dan Minuman di Kabupaten Pasuruan dalam meningkatkan pendepatan guna mempertahankan usahanya dalam menghadapi revolusi industri 4.0. Alat analisis yang digunakan pada tahap ini menggunakan matriks IE (Internal-External) dan analisis SWOT.

Tabel 5. Matriks internal - eksternal

\begin{tabular}{cccc}
\hline \multicolumn{1}{c}{ IFAS } & Kuat & Sedang & Lemah \\
EFAS & $4,00-3,00$ & $2,99-2,00$ & $1,99-1,00$ \\
\hline Tinggi & I & II & III \\
$4,00-3,00$ & & & VI \\
$\begin{array}{c}\text { Sedang } \\
2,99-2,00\end{array}$ & IV & V & \\
Rendah & & Internal $=\mathbf{2 , 8 1}$ & Eksternal $=\mathbf{2 , 3 2}$ \\
$1,99-1,00$ & VII & VIII & IX \\
\hline
\end{tabular}

Sumber : Data diolah, 2021

Berdasarkan matriks IE posisi UMKM makanan dan minuman untuk meningkatkan pendapatan guna mempertahankan kelangsungan usaha dalam menghadapi Era Revolusi Industri 4.0 Kabupaten Pasuruan terletak pada Sel V. Posisi ini berada pada posisi identifikasi, pertumbuhan segmen, pilihan investasi dan spesialisasi. Strategi yang dapat diterapkan Strenghts Opportunities (SO) dengan memaksimalkan kekuatan dan memperhatikan peluang pasar. Strategi ini perlu didukung mengingat akan yang menjadi kekuatan usaha mikro adalah kemampuan SDM yang kreatif, produk yang selalu unik, harga yang murah, mutu pelayanan, lokasi yang strategis serta bahan baku yang mudah di peroleh.

\section{Analisis SWOT}

Hasil analisis SWOT pada tabel 6 menunjukkan posisi UMKM Makanan dan Minuman di Kabupaten Pasuruan pada sel V matrik IE. Strategi internal 
mempunyai kekuatan yang cukup baik dan secara eksternal pada posisi sedang. Posisi pada sel V matrik IE menunjukkan kondisi usaha dalam posisi identifikasi, pertumbuhan segmen, seleksi investasi dan spesialisasi. Dalam masa posisi identifikasi, pertumbuhan segmen, seleksi investasi dan spesialisasi maka diperlukan strategi yang tepat untuk meningkatkan pendapatan di masa pandemi covid-19 guna mempertahankan kelangsungan usaha di era revolusi industri 4.0. Pada Tabel 6 menunjukkan nilai 3,7 maka strategi yang tepat yaitu Strenghts Opportunities (SO) dengan merumuskan hal berikut usaha mikro makanan dan minuman di Kabupaten Pasuruan untuk pemilihan bahan baku yang mudah diperoleh akan memberikan peluang untuk memenuhi kebutuhan masyarakat yang konsumtif sehingga dapat meningkatkan loyalitas pelanggan di mana . kemudahaan perolehan bahan baku ini tentunya tidak lepas dari peran pemerintah daerah melalui kebijakannya (S6O2).. Usaha mikro makanan dan minuman di Kabupaten Pasuruan Harga yang relative murah menjadi kekuatan untuk memenuhi kebutuhan konsumen dari berbagai sektor kalangan masyarakat dengan memanfaatkan adanya aplikasi online (S1O4) sehingga dapat meningkatkan peluang usaha. Usaha mikro makanan dan minuman di Kabupaten. Usaha mikro makanan dan minuman di Kabupaten Pasuruan Kegiatan yang dilakukan pada tempat dan lokasi yang strategis serta produk yang unit dengan memanfaatkan peluang kemajuan teknologi akan memberikan perluasan pasar. ( 2 2;O5). hal ini sesuai dengan penelitian yang dilakukan oleh Wastutiningsih and Dewi (2019) Adapun hasil penelitian menunjukkan adanya fungsi manifes berupa peningkatan jumlah penjualan dan omzet yang diperoleh pengusaha melalui digital marketing sedangkan fungsi latennya berupa perubahan gaya hidup masyarakat perdesaan yang menjadi konsumtif semenjak mengenal dunia internet. Strategi SO sebagai strategi utama yang harus dilakukan akan tetapi strategi ST yaitu dengan cara menciptakan strategi yang meminimalkan kelemahan dan menghindari ancaman secara langsung di dalam lingkungan Eksternal, strategi WO yaitu dengan cara menciptakan strategi yang meminimalkan kelemahan untuk memanfaatkan peluang besar yang ada dan Strategi WT yaitu dengan cara menciptaan strategi yang menggunaan kekuatan untuk mengatasi ancaman dari eksternal. Hasil analisis SWOT dan matrik IE hanya suatu strategi namun tidak bersifat mutlak (Sondang, P.Siagian, 2000 dan Pearce, J. A. dan Robinson, R. B. 2008).

\section{KESIMPULAN DAN SARAN}

\section{Kesimpulan}

Hasil penelitian bahwa Matrix Internal Factors (IFAS) dan External Factors (EFAS) menunjukkan bahwa UMKM pada usaha makanan dan minuman terletak di sel V berada pada posisi identifikasi, pertumbuhan segmen, pilihan investasi dan spesialisasi. Strategi yang harus dilakukan usaha mikro makanan dan minuman di Kabupaten Pasuruan dalam meningkatkan pendapatan guna mempertahankan kelangsungan usahanya menghadapi revolusi industri 4.0. di masa pandemi covid 19 yaitu pada Strength Opportunity (SO) dengan cara menciptakan strategi yang menggunaan kekuatan untuk memanfaatkan peluang eksternal.

\section{Saran}

Bagi Dinas Koperasi dan Usaha Mikro Kabupaten Pasuruan agar selalu memberikan dukungan kepada para UMKM guna menjawab permasalahan yang 
dihadapi, baik secara finansial maupun non finansial, Untuk peneliti selanjutnya yang lebih fokus pada strategi pemasaran dan strategi pengembangan UMKM. Penelitian ini diharapkan menjadikan sumber inspirasi dan motivasi untuk mengadakan penelitian lain pada obyek yang berbeda dan alat analisis yang berbeda untuk membantu para pengusaha UMKM mengatasi permasalahan-permasalah yang mereka hadapi sehingga mampu membuka peluang lapangan kerja baru, mampu bersaing dengan produk impor.

\section{DAFTAR PUSTAKA}

Amri, A. (2020). Dampak Covid-19 terhadap UMKM di Indonesia. Jurnal Brand.2(1), 123-130

Andika, R., Pratiwi, S., Anisa, A., \& Putri, S. A. (2020). Dampak Covid-19 terhadap pendapatan pedagang mikro pada pasar tradisional. Jurnal Ekonomi Islam AlSharf.1(1), 16-22

Ayu. (2020). Strategi pemasaran dalam meningkatkan penjualan pada Toko Bag Corner Ponorogo. In pembelajaran olah vokal di prodi seni pertunjukan Universitas Tanjungpura Pontianak.

Bahtiar, R. A., \& Saragih, J. P. (2020). Dampak Covid-19 terhadap perlambatan ekonomi sektor umkm. Jurnal Bidang Ekonomi Dan Kebijakan Publik, 7 (6),19-24.

Hardilawati, W. laura. (2020). Strategi bertahan UMKM di tengah Pandemi Covid-19. Jurnal Akuntansi dan Ekonomika. 10(1), 89-98, https://doi.org/10.37859/jae. v10i1.1934

Harian Netral. (2014). Pengertian strategi menurut beberapa ahli. Harian Netral.

Koch, V., Kuge, S., Geissbauer, R., \& Schrauf, S. (2014). Industry 4.0 - opportunities and challenges of the industrial internet. Strategy\& Formerly Booz \& Company, $P w C .13,1-52$

Mesran.dkk. (2020). Pengembangan UMKM, Pariwisata dan ekonomi kreatif dalam masa Covid-19 dan new normal. In Merdeka Kreatif di Era Pandemi Covid-19.

Ramadhan. (2020). Strategi Pemulihan UMKM di Masa New Normal. Asumsi diakses dalam,https://www.asumsi.co/post/strategi-pemulihan-ekonomi-UMKM-dimasa new-normal, Tanggal 20 Agustus 2021.

Satiti, Pilar and Wafrotur Rohmah. (2014). Pengaruh pendapatan dan peran aparat kelurahan terhadap kesadaran masyarakat dalam membayar pajak bumi dan bangunan di Semanggi RW VIII Pasar Kliwon Surakarta Tahun 2013. Skripsi. Universitas Muhammadiyah Surakarta

Schumacher, A., Erol, S., \& Sihn, W. (2016). A Maturity model for assessing industry 4.0 readiness and maturity of manufacturing enterprises. 52:161-166, Procedia CIRP. https://doi.org/10.1016/j.procir.2016.07.040

Sedyastuti, K. (2018). Analisis pemberdayaan UMKM Dan peningkatan daya saing dalam kancah pasar global. INOBIS: Jurnal Inovasi Bisnis dan Manajemen Indonesia. 2(1), 117- 127, https://doi.org/10.31842/jurnal-inobis.v2i1.65

Senekal, B. (2021). The first 40 years of Orania. Tydskrif Vir Geesteswetenskappe. , 61(2),526-550,, https://doi.org/10.17159/2224-7912/2021/v61n2a8

Hanoatubun,S.(2020).Dampak Covid-19 terhadap prekonomian Indonesia. EduPsyCouns: Journal of Education, Psychology and Counseling, 2(1), 146153. Retrieved from https://ummaspul.e-journal.id/Edupsycouns/article/view/ 423 
Sugiri, D. (2020). Menyelamatkan usaha mikro, kecil dan menengah dari dampak pandemi Covid-19. Fokus Bisnis: Media Pengkajian Manajemen dan Akuntansi. 19, 1 (Jul. 2020), 76-86, https://doi.org/10.32639/fokusbisnis. v19i1.575

Suharsimi, A. (2006). Prosedur penelitian suatu pendekatan praktik. Rineka Cipta: Jakarta.

Sularsih, H., \& Nasir, A. (2020). Strategi usaha mikro kecil dan menengah (umkm) dalam menghadapi era revolusi industri 4.0 Di Kabupaten Pasuruan. Referensi: Jurnal Ilmu Manajemen dan Akuntansi, 8(2), 65-73.

Susanti, A., Istiyanto, B., \& Jalari, M. (2020). Strategi UKM pada masa pandemi Covid19. KANGMAS: Karya Ilmiah Pengabdian Masyarakat. 1(2), 67-74 https://doi.org/10.37010/kangmas.v1i2.50

Thaha, A. F. (2020). Dampak Covid-19 terhadap UMKM di Indonesia. Jurnal Brand. 2(1), 147-153

Zhou, K., Liu, T., \& Zhou, L. (2016). Industry 4.0: towards future industrial opportunities and challenges. 2015 12th International Conference on Fuzzy Systems and Knowledge Discovery, FSKD 2015. 2147-2152. https://doi.org/10.1109/ FSKD.2015.7382284 